\title{
Lactoferrin Acts on Ia-like Antigen-Positive Subpopulations of Human Monocytes to Inhibit Production of Colony Stimulatory Activity In Vitro
}

\author{
HAL E. BRoXmeyer, Sloan-Kettering Institute for Cancer Research, \\ Laboratories of Developmental Hematopoiesis, New York 10021
}

\begin{abstract}
A в S T R A C T The relationship between Ia-like antigens (Ia-antigens) on human monocytes and the ability of lactoferrin (LF) to inhibit the production of colony stimulatory activity (CSA) for granulocyte and macrophage colony formation was investigated. Complement-dependent cytotoxicity of human monocytes by antiserum to Ia-antigen-reduced CSA production by $50 \%$. LF decreased CSA production by monocytes but had no influence on monocytes insensitive to anti-Ia and complement. Anti-Ia in the absence of complement had no effect on production of CSA but blocked the inhibitory action of LF. This suggests that LF inhibits production of CSA from an Ia-antigen-positive subpopulation of human blood monocytes. This may be of relevance to the regulation of myelopoiesis.
\end{abstract}

\section{INTRODUCTION}

Regulation of myelopoiesis entails interactions between progenitor cells committed to granulocytemacrophage differentiation and stimulatory and inhibitory substances derived from the mature end cells of these lineages (1). A main cellular source of colony stimulatory activity $(\mathrm{CSA})^{1}$ for granulocytes and macrophages in humans appears to be the monocyte-macrophage series (1). Human CSA, candidate in vivo regulators, are macromolecules that induce progenitor cells from bone marrow to form colonies of granulocytes and/or macrophages in semisolid culture (1). The in vitro and in vivo production of CSA and myelopoiesis in vivo can be suppressed by lactoferrin (LF), an ironbinding glycoprotein found in the secondary granules

Dr. Broxmeyer is a Scholar of the Leukemia Society of America.

Received for publication 6 August 1979 and in revised form 19 September 1979.

${ }^{1}$ Abbreviations used in this paper: Ia-antigen, Ia-like antigen; LF, lactoferrin; CSA, colony stimulatory activity for granulocyte-macrophage colony formation; FCS, fetal calf serum. of polymorphonuclear neutrophils $(2,3)$. LF has no direct effect on the progenitor cells (2).

A proportion of human monocytes (4-6) and macrophages (7) contain Ia-like (Ia) antigenic determinants. The 28,000-37,000 dalton complex isolated from human B-cell line membranes and produced by genes mapping in the major histocompatibility complex (8) is biochemically similar to the murine I region antigenic (Ia) system.

In the present study, the ability of Ia-antigen-positive subpopulations of human monocytes to produce CSA and the possible relationship of Ia-antigens to receptors for $L F$ were investigated.

\section{METHODS}

Bone marrow and blood were obtained from normal volunteers who had given informed consent. Nucleated bone marrow and blood cells were separated by a density "cut" procedure with bovine serum albumin $\left(1.070 \mathrm{~g} / \mathrm{cm}^{3}, 270 \mathrm{mosmol}\right)$ (1). Low density $\left(<1.070 \mathrm{~g} / \mathrm{cm}^{3}\right)$ bone marrow cells were further separated by adherence to plastic (1) to obtain nonadherent low density cells depleted of cells that produce CSA and contained $>98 \%$ of the granulocyte-macrophage colony-forming cells. Low density blood cells, composed of $\sim 50 \%$ lymphocytes and $50 \%$ monocytes as determined by Wright's and nonspecific esterase staining (9), were used as the cellular source of CSA or were further separated by adherence to plastic to obtain adherent mononuclear cells (>90\% monocytes) (1). Cell viability was assessed using trypan blue stain.

Complement-dependent cytotoxicity and complement-independent studies. Ia-antigen-specific heteroantiserum absorbed against $\mathrm{T}$ cells and the $\mathrm{B}$ cell-absorbed control sample were generously supplied by Dr. Robert Winchester of The Rockefeller University, New York (4). Dilutions of antiserum or control serum were prepared in McCoy's medium supplemented with $10 \%$ heat-inactivated fetal calf serum (FCS). Mononuclear blood cells $\left(5 \times 10^{6}\right)$ in $1.0 \mathrm{ml}$ were incubated with $1.0 \mathrm{ml}$ of antiserum at $4^{\circ} \mathrm{C}$ for $30 \mathrm{~min}$, washed through FCS, and used or incubated at $37^{\circ} \mathrm{C}$ for $45 \mathrm{~min}$ with $1.0 \mathrm{ml}$ of rabbit complement preselected for absence of heterospecific antibodies (1:10 dilution) and washed through FCS twice (4). In some experiments the adherent mononuclear cells were exposed to the antiserum. 
$L F$. Lactoferrin (Metallo Protein Laboratories, Ltd., Windsor, Canada) was fully iron saturated (2), dialyzed against phosphate-buffered saline for $24 \mathrm{~h}$, and passed through an Amberlite ion exchange IRA 401 column (Mallinckrodt Inc., St. Louis, Mo.) to remove free metal.

Colony assay. Nonadherent low density bone marrow cells $\left(0.8-1.0 \times 10^{5}\right)$ were plated in $0.3 \%$ agar in supplemented McCoy's medium with $10 \%$ heat-inactivated FCS over feeder layers of mononuclear blood cells suspended in $0.5 \%$ agar-culture medium, over $0.5 \%$ agar-culture medium layered over adherent mononuclear cells or over culture medium conditioned by adherent mononuclear cells (1). Colonies ( $>50$ cells) and clusters ( $3-50$ cells) were scored after $7-10 \mathrm{~d}$ of incubation. The data are expressed as mean $\pm \mathrm{SE}$ based on counting of five replicate plates. The probability of differences between samples was determined by the use of the Student's $t$ test.

\section{RESULTS}

Fig. 1A shows one of five similar experiments demonstrating complement-dependent inhibition of the production of CSA from human mononuclear blood cells by a 1:40 dilution of the antiserum to Ia. Treatment of the cells with anti-Ia plus complement inhibited CSA production $48-53 \%$; this was similar to the suppression of CSA production noted with $0.1 \mu \mathrm{M}$ LF. Cells surviving treatment with antiserum to Ia plus complement were not responsive to suppression by LF. Control serum plus complement or complement alone had no influence on production of CSA or on the inhibition of CSA production by LF. Titration of com- plement-dependent inhibition of CSA production by anti-Ia, shown as the average of two experiments in Fig. 2A, demonstrated inhibition of CSA production which plateaued at $52 \%$ using $1: 40$ to $1: 640$ dilutions of anti-Ia. Dilutions of anti-Ia $>1: 2,500$ suppressed CSA production with decreasing efficiency. LF did not further suppress CSA production by the cells treated with $1: 40$ to $1: 2,500$ dilutions of anti-Ia, but LF maintained maximum inhibition of CSA production after treatment of the cells with higher dilutions of anti-Ia.

Treatment of mononuclear blood cells with anti-Ia (1:40 dilution) without complement negated the LFmediated inhibition of CSA production (Fig. 1B, one of six similar experiments). Anti-Ia without complement did not reduce production of CSA but did block the influence of $0.1 \mu \mathrm{M} L F$ in this experiment and $1 \mu \mathrm{M}$ to $0.1 \mathrm{mM} \mathrm{LF}$ in two other experiments. Titration of the complement-independent blocking of LF action by anti-Ia is shown as the average of two experiments in Fig. 2B. Suppression of CSA production by LF is completely blocked by 1:40 to $1: 160$ dilutions and partially blocked by 1:640 to 1:2,500 dilutions of anti-Ia.

$40-46 \%$ of blood monocytes from three normal donors were killed by a 1:100 dilution of anti-Ia plus complement, and the above results were confirmed for adherent mononuclear blood cells ( $>90 \%$ monocytes) as shown in Fig. 3. LF $(0.1 \mu \mathrm{M})$ suppressed CSA production by cells pretreated with control medium or complement before adherence of the cells to plastic.

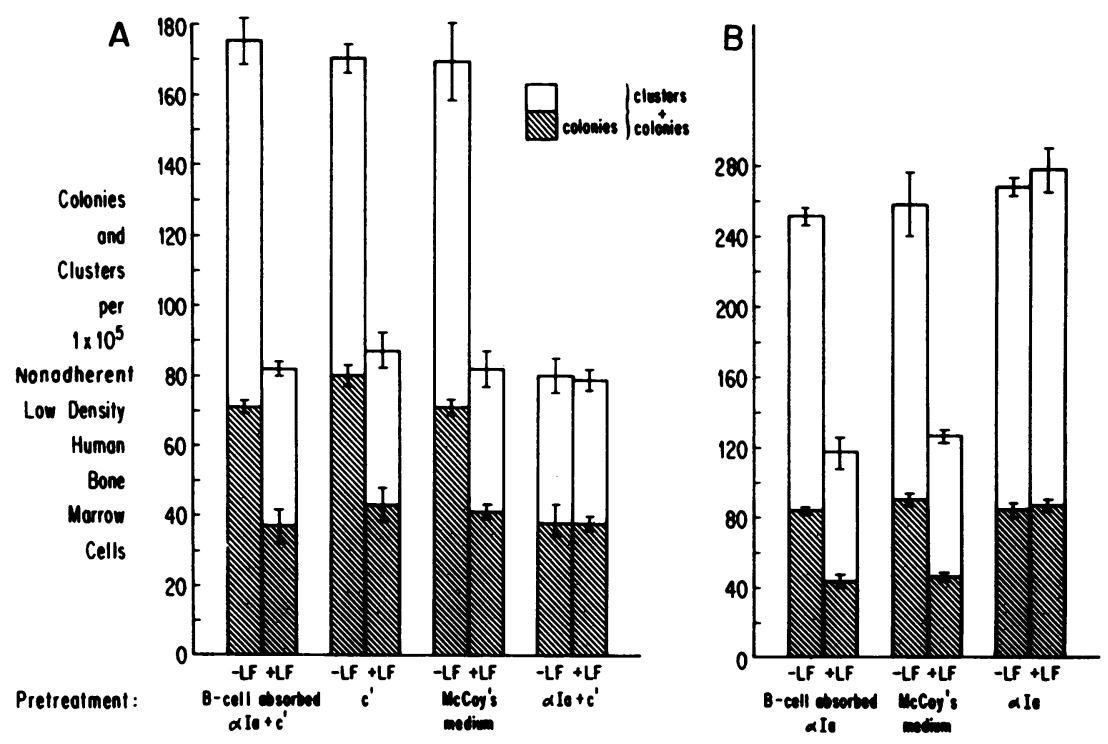

FIgURE 1 Effect of antiserum to human Ia-antigen on production of CSA from $0.5 \times 10^{6}$ human mononuclear blood cells and on inhibition of CSA production by LF. (A) Cells were pretreated with a 1:40 dilution of the control B-cell absorbed anti-Ia plus complement $\left(\mathrm{C}^{\prime}\right), \mathrm{C}^{\prime}$, McCoy's medium, or a 1:40 dilution of anti-Ia $+C^{\prime}$. (B) Cells were pretreated with a 1:40 dilution of B-cell absorbed anti-Ia, McCoy's medium, or a 1:40 dilution of anti-Ia. Treated and untreated cells were plated as if there were still $0.5 \times 10^{6}$ cells per milliliter in under layers of agar with or without $0.1 \mu \mathrm{M}$ LF and assayed for stimulation of colony formation of bone marrow cells immobilized in an agar overlayer. 


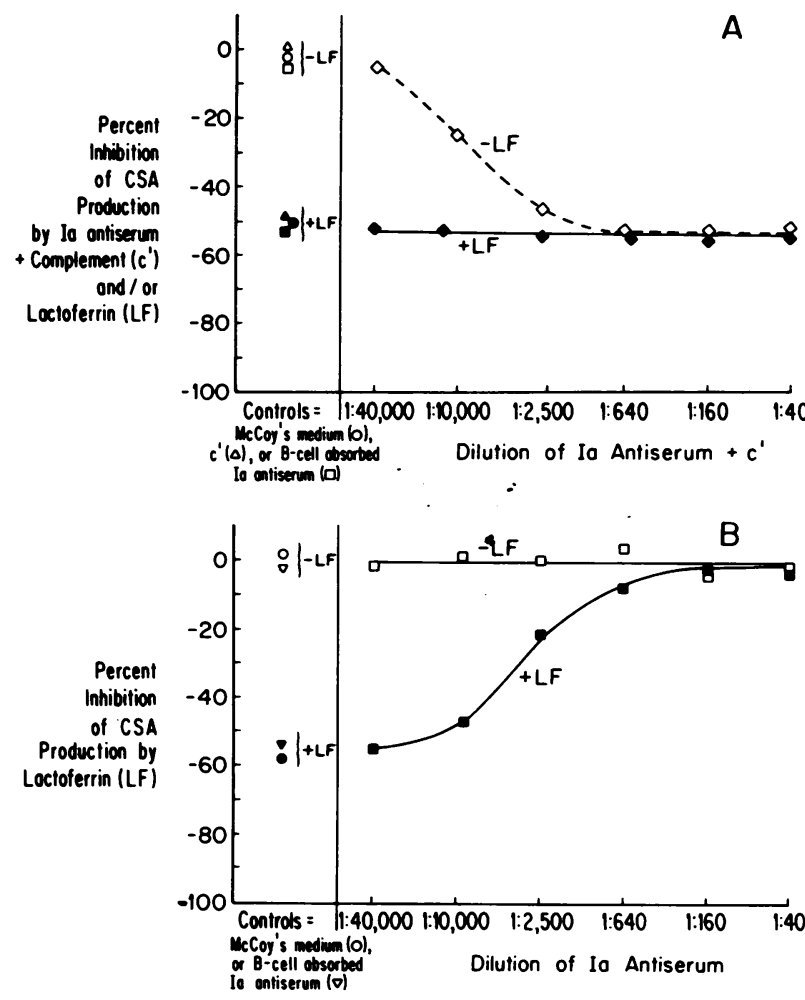

Figure 2 Effect of various dilutions of anti-Ia on production of CSA from $0.5 \times 10^{6}$ human mononuclear blood cells and on inhibition of CSA production by LF. (A) Cells were pretreated with McCoy's medium, complement $\left(C^{\prime}\right)$, or various dilutions of the control B-cell absorbed anti-Ia, or anti-Ia plus $\mathrm{C}^{\prime}$. (B) Cells were treated with McCoy's medium, B-cell absorbed anti-Ia, or anti-Ia. The treated cells were incorporated into agar under layers with or without $0.1 \mu \mathrm{M} \mathrm{LF}$ and assessed for their production of CSA as in Fig. 1. Parts A and B are the mean results of two experiments.

Antiserum to Ia (1:100 dilution) plus complement suppressed CSA production; this inhibition was similar to that caused by LF. However, LF did not suppress CSA production from the cells surviving treatment with anti-Ia plus complement (Fig. 3A). Similar results were obtained when medium conditioned by $0.4 \times 10^{5}$ treated blood monocytes from two normal donors was assessed for production of CSA. Antiserum to Ia (1:100 dilution) plus complement reduced CSA production by $45-55 \%$. LF $(0.1 \mu \mathrm{M})$ reduced CSA production from complement-treated cells by $48-59 \%$, but had no influence on the cells treated with anti-Ia plus complement. Antiserum to Ia does not cause the release of monocyte-derived inhibitors against CSA or the colony-forming cells. Medium conditioned by monocytes treated with anti-Ia plus complement $\left(\mathbf{C}^{\prime}\right)$, or complement alone, did not reduce colony formation stimulated maximally $\left(81 \pm 3\right.$ control, $83 \pm 5$ anti-Ia $+C^{\prime}$, $85 \pm 5 C^{\prime}$ ) by human placental cell conditioned medium. Treatment of cells with control medium or serum (1:100

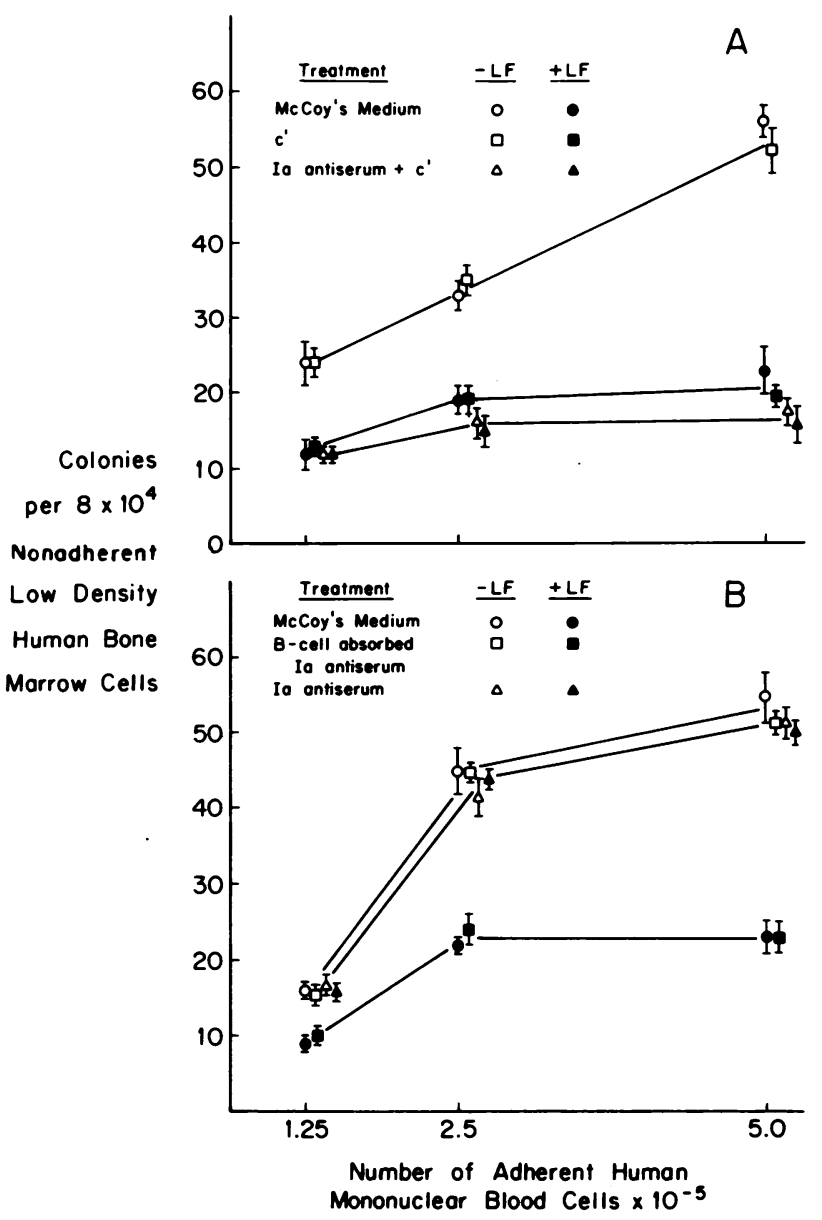

FIGURE 3 Effect of anti-Ia on production of CSA from human monocytes and on inhibition of CSA production by LF. (A) Mononuclear blood cells were pretreated with McCoy's medium, complement $\left(C^{\prime}\right)$ or anti-Ia $(1: 100)$ plus $C^{\prime}$ before adhering the cells to plastic Petri dishes. (B) Mononuclear blood cells were adhered to plastic and subsequently treated with McCoy's medium, B-cell absorbed anti-Ia (1:100), or anti-Ia (1:100). Adherent cells (>90\% monocytes) were assessed for their capacity to stimulate colony formation in the presence and absence of $0.1 \mu \mathrm{M} \mathrm{LF}$.

dilution) after they had adhered to plastic did not influence CSA production or inhibition of CSA production mediated by $0.1 \mu \mathrm{M}$ LF. Anti-Ia (1:100 dilution) did not effect CSA production, but did block the suppressive influence of LF (Fig. 3B). CSA production was confined to the monocyte fraction as nonadherent mononuclear blood cells ( $>98 \%$ lymphocytes) produced little or no CSA ( $<10$ clusters) when plated at $0.25-2.0 \times 10^{6}$ cells $/ \mathrm{ml}$.

\section{DISCUSSION}

Human monocytes (4-6) and macrophages (7) are heterogeneous with respect to the presence of Ia-anti- 
gens on their surface. It is clear from the present studies that Ia-antigen-positive and Ia-antigen-negative human monocytes produce CSA but it is the Ia-antigenpositive subpopulation of monocytes that is inhibited from producing and/or releasing CSA by LF.

Ia-antigens are present on other hematopoietic cells (4) but the blocking of LF action on monocytes by anti-Ia suggests an intimate association between Iaantigens and LF. It has been suggested that human monocytes and mouse macrophages contain specific receptors for LF (10). Thus, Ia-antigens can act as receptors for LF, Ia-antigens and receptors for LF are structurally different but are in close spatial proximity, or a ligand-induced alteration of Ia-antigens may lead to an interaction with the receptors for LF. LF has been shown to act in vivo in mice (2) and the presence of Ia-antigen-positive monocytes may be of significance to the regulation of myelopoiesis in man. This interaction could depend on heterogeneity of Ia-antigen expression on monocytes, shedding and replacement of Ia-antigens, and the presence of substances that might be able to modulate the numbers or position of Iaantigens on the cell surface. Furthermore, disturbances in the interaction of $\mathrm{LF}$ and Ia-antigen-positive monocytes may be involved in the myelopoietic hyperplasia noted in certain leukemias (1).

\section{ACKNOWLEDGMENTS}

I thank Drs. Robert Winchester, Maria de Sousa, Paul Kincade, Louis Pelus, Peter Ralph, and Neil Williams for their helpful suggestions and comments, and Harriet Shields and the Secretarial Service of Sloan-Kettering Institute for typing the manuscript.

This work was supported by grant $\mathrm{CH}-138$ from the American Cancer Society, U. S. Public Health Service grants CA-
23528 and CA-08748 from the National Cancer Institute, and the Gar Reichman Foundation.

\section{REFERENCES}

1. Broxmeyer, H. E., and M. A. S. Moore. 1978. Communication between white cells and the abnormalities of this in leukemia. Biochim. Biophys. Acta. 516: 129-166.

2. Broxmeyer, H. E., A. Smithyman, R. R. Eger, P. A. Meyers, and M. de Sousa. 1978. Identification of lactoferrin as the granulocyte-derived inhibitor of colony-stimulating activity production. J. Exp. Med. 148: 1052-1067.

3. Broxmeyer, H. E. 1978. Inhibition in vivo of mouse granulopoiesis by cell-free activity derived from human polymorphonuclear neutrophils. Blood. 51: 889-901.

4. Winchester, R. J., G. D. Ross, C. I. Jarowski, C. Y. Wang, J. Halper, and H. E. Broxmeyer. 1977. Expression of Ialike antigen molecules on human granulocytes during early phases of differentiation. Proc. Natl. Acad. Sci. U. S. A. 74: 4012-4016.

5. Winchester, R. J., C. Y. Wang, J. Halper, and T. Hoffman. 1976. Studies with B-cell allo- and hetero-antisera: parallel reactivity and special properties. Scand. J. Immunol. 5: 745-757.

6. Snary, D., C. J. Barnstable, W. F. Bodmer, P. N. Goodfellow, and M. J. Crumpton. 1977. Cellular distribution, purification and molecular nature of Ia antigens. Scand. J. Immunol. 6: 439-452.

7. Albrechtsen, D. 1977. HLA-D-associated "Ia-like" antigens on human macrophages. Scand. J. Immunol. 6: 907-912.

8. Winchester, R. J., S. M. Fu, P. Wernet, H. G. Kunkel, B. Dupont, and C. Jersild. 1975. Recognition of non-HLA alloantigens selectively expressed on B-lymphocytes. J. Exp. Med. 141: 924-929.

9. Koski, I. R., D. G. Poplack, and R. M. Blaese. 1976. A non-specific esterase stain for the identification of monocytes and macrophages. In In Vitro Methods in Cell Mediated and Tumor Immunology. B. R. Bloom and J. R. David, editors. Academic Press, Inc., New York. 359-362.

10. Van Snick, J. L., and P. L. Masson. 1976. The binding of human lactoferrin to mouse peritoneal cells. J. Exp. Med. 144: $1568-1580$. 